Check for updates

Cite this: RSC Adv., 2019, 9, 12801

Received 5th March 2019

Accepted 1st April 2019

DOI: 10.1039/c9ra01679a

rsc.li/rsc-advances

\section{One-pot synthesis of 2-amino-4H-chromene derivatives by MNPs@Cu as an effective and reusable magnetic nanocatalyst $\uparrow$}

\author{
Wanzheng MA, ${ }^{a}$ Abdol Ghaffar Ebadi, ${ }^{b}$ Mostafa shahbazi sabil, ${ }^{c}$ Ramin Javahershenas ${ }^{d}$ \\ and Giorgos Jimenez (D) *e
}

In this research, MNPs@Cu as an effective and recyclable nanocatalyst was prepared and characterized using different methods including Fourier transform infrared spectroscopy (FT-IR), thermogravimetric analysis (TGA), vibrating sample magnetometry (VSM), scanning electron microscopy (SEM), energy dispersive X-ray spectroscopy (EDX), and X-ray diffraction (XRD). After the characterization of this new nanocatalyst, it was efficiently used for the promotion of the one-pot synthesis of 2-amino- $4 \mathrm{H}$ chromene derivatives via one-pot three-component reaction of the enolizable compound, malononitrile, and arylaldehydes under solvent-free conditions at $90^{\circ} \mathrm{C}$. The procedure gave the desired products in high-to-excellent yields in short reaction times. Also this catalyst, because of its magnetic nature, can be simply restored by a permanent magnetic field and comfortably reused several times without any significant loss of its catalytic activity.

\section{Introduction}

Heterocyclic compounds have wide applications and are essential in various pharmaceutical compounds. One of the key reasons for the widespread use of heterocyclic compounds is constructing various structures to achieve the desired functions. ${ }^{1,2}$ Oxygen-bearing heterocyclic molecules such as $4 H^{-}$ pyrans and $4 H$-pyran-annulated heterocyclic scaffolds $\left(4 H^{-}\right.$ chromene moieties) are very important because of their ubiquitous presence in nature and provision of appropriate biological activity, which make them an interesting issue for many researchers in organic chemical science. These structural motifs are very beneficial derivatives that develop activities such as anti-HIV, anti-tumor, antimicrobial, anti-inflammatory, antifungal, and anti-allergenic with respect to the available substituents in the structure. ${ }^{3-12}$

Moreover, it has been observed that pyran-containing heterocyclic compounds are widespread in nature and their uses in pharmaceuticals, biodegradable agrochemicals, pigments, and cosmetics industries are becoming more and

${ }^{a}$ Resource and Environmental Engineering College, Anhui Science and Technology University, Fengyang 233100, China

${ }^{b}$ Department of Agriculture, Jouybar Branch, Islamic Azad University, Jouybar, Iran

'Department of Chemical Engineering, Graduated from Petroleum University of Ahvaz, Iran

${ }^{d}$ Department of Organic Chemistry, Faculty of Chemistry, Urmia University, 5756151818, Urmia, Iran

eUniversity of Tirana, Tirana, Albania.E-mail: jimenezgiorgos@gmail.com

$\dagger$ Electronic supplementary information (ESI) available. See DOI: 10.1039/c9ra01679a more important. ${ }^{13-16}$ Natural resources for preparing these compounds are limited and, in most cases, it is required to handle a difficult process for the isolation and purification of them. Therefore, to synthesize compounds from this group, many efforts have been made to investigate derivatives progress and their medicinal features. ${ }^{17-25}$ Many procedures have been developed for the preparation of functionalized 2-amino- $4 H^{-}$ chromenes via one-pot Knoevenagel condensation of $\mathrm{C}-\mathrm{H}-$ activated acids, aldehydes, and malononitrile using catalysts such as SDS, ${ }^{17}$ DAHP,${ }^{26}$ MNP@AVOPc,${ }^{27}[$ Sipim $] \mathrm{HSO}_{4}{ }^{28}$ nano $\mathrm{Al}_{2} \mathrm{O}_{3},{ }^{29}$ POPINO, ${ }^{30} \mathrm{CuO}$ nanoparticles ${ }^{31}$ and TBBDA. ${ }^{32}$ Some of these procedures suffer from one or more limitations, such as low yields of the desired product, long reaction times, toxicity, poor recovery and reusability of the catalyst, and tedious workup. Therefore, a great demand still exists for simple, versatile, and environmentally friendly processes for the synthesis 2amino- $4 H$-chromene derivatives under simple conditions.

In green chemistry, scientists are trying to develop, design, and implement ways to prevent the use or generation of hazardous substances in chemical processes. Although innovation processes with environmentally friendly solvents provide a perfect solution to overcome these problems, in most cases, the solvent-free conditions in chemical processes play an inevitable role. Nowadays, solvent-free procedures in the existence of magnetic nanoparticles as a catalyst have eliminated most of the problems associated to the use of organic solvents for avoiding tedious separation procedures through extraction or distillation. Metal-catalysis has played a fundamental role in the prosperity of the industry. ${ }^{33}$ The utilization of transition-metal nanoparticles in catalysis is definitive as they assume metal 
surface activation and catalysis at the nanoscale and thereby afford efficiency and selectivity to heterogeneous catalysis. ${ }^{34-37}$ Magnetic nanoparticles and analysis of their manipulation in the manufacturing of fine heterogeneous catalysis synthesis have achieved a major area of research as an effective material because of their good stability, low toxicity, easy synthesis, and functionalization, and large surface area. ${ }^{38-42}$ Due to lose dispersibility and catalytic activity through anisotropic dipolar attraction of the $\mathrm{Fe}_{3} \mathrm{O}_{4}$ nanoparticles, these kinds of uncoated nanoparticles with metal oxides can be easily aggregate into large clusters. ${ }^{43}$ The acidic environment also causes the loss of their magnetic properties. It is essential to note that relatively small $\mathrm{Fe}_{3} \mathrm{O}_{4}$ nanoparticles may tolerate rapid biodegradation when they are directly exposed to biological systems. ${ }^{44}$ The suitable coating with a protective shell of silica to form a coreshell structure is essential to overcome such limitation. ${ }^{45}$ Therefore, the use of magnetic coated nanoparticles as suitable alternative supports for the functionalization of organic compounds in the preparation of heterogeneous catalysis is of paramount importance.

\section{Experimental}

\section{General}

All the pure chemicals were prepared from Merck and Fluka chemical companies. Separation and purification of the products were performed with extraction and recrystallization techniques. Melting points were determined with an Electrothermal-9100 apparatus and no correction was made. FT-IR spectra were obtained by means of a PerkinElmer PXI spectrometer in $\mathrm{KBr}$ wafers. TGA analysis was conducted using a TGA thermoanalyzer (PerkinElmer) instrument. Samples were heated from 25 to $800{ }^{\circ} \mathrm{C}$ at $\operatorname{ramp} 10{ }^{\circ} \mathrm{C} \mathrm{min}{ }^{-1}$ under an $\mathrm{N}_{2}$ atmosphere. The X-ray diffraction (XRD) measurements of catalyst were performed with a Siemens D-500 X-ray diffractometer (Munich, Germany). Scanning electron microscopy was accomplished using an SEM-LEO 1430VP analyzer. Magnetic susceptibility measurements were accomplished using a vibrating sample magnetometer (VSM/AGFM, MDK Co, Ltd, Iran) in the magnetic field range of -8000 Oe to 8000 Oe at ambient temperature. Magnetic susceptibility measurements were performed by a VSM/AGFM (MDK Co, Ltd, Iran) in the magnetic field range of -8000 Oe to 8000 Oe at $25^{\circ} \mathrm{C}$. Elemental analyses were carried out on a Carlo-Erba EA1110CNNO-S analyzer and agreed (within 0.30) with the calculated values.

\section{Catalyst synthesis}

Preparation of MNPs. This precursor was prepared according to the chemical co-precipitation method. To prepare MNPs, $5.2 \mathrm{~g}$ of $\mathrm{FeCl}_{3} \cdot 6 \mathrm{H}_{2} \mathrm{O}$ and $2 \mathrm{~g}$ of $\mathrm{FeCl}_{2} \cdot 4 \mathrm{H}_{2} \mathrm{O}$ were poured into a $250 \mathrm{~mL}$ flask reaction containing $40 \mathrm{~mL}$ deoxygenated water followed by adding $0.9 \mathrm{~mL}$ of concentrated $\mathrm{HCl}$ under a continuous flow of nitrogen gas. Next, $250 \mathrm{~mL}$ of $\mathrm{NaOH}$ solution (1.5 M) was poured dropwise into the reaction solution and stirred until the reaction was completed. After this period, the resulting black MNPs were magnetically separated and rinsed with deionized water and dried at $40{ }^{\circ} \mathrm{C}$ for $24 \mathrm{~h}$.

Preparation of MNPs@SiO $_{2}$. About $1 \mathrm{~g}$ of MNPs was dispersed in a mixture containing water $(5 \mathrm{~mL})$, ethanol (45 $\mathrm{mL}$ ), and concentrated aqueous ammonia ( $3 \mathrm{~mL}, 25 \mathrm{wt} \%)$ by ultrasonication. Next, $0.5 \mathrm{~mL}$ of tetraethylorthosilicate (TEOS) was poured and the mixture was mechanically stirred for $24 \mathrm{~h}$ at room temperature. After this period, the precipitates of coreshell MNPs@SiO $\mathrm{S}_{2}$ nanoparticles were collected by an external magnetic and washed several times with ethanol. Finally, the MNPs@SiO ${ }_{2}$ precipitate was dried under vacuum oven at $70{ }^{\circ} \mathrm{C}$ for $5 \mathrm{~h}$.

Preparation of MNPs bonded propyl chloride (MNPs@PC). In the following step, $1 \mathrm{~g}$ of core-shell $\mathrm{Fe}_{3} \mathrm{O}_{4} @ \mathrm{SiO}_{2}$ nanoparticles was dispersed in $20 \mathrm{~mL}$ dry toluene with the aid of ultrasonication for $20 \mathrm{~min}$. Next, $2 \mathrm{~mL}$ of 3-chloropropyltriethoxysilane (CPTCSi) was poured in to the reaction solution

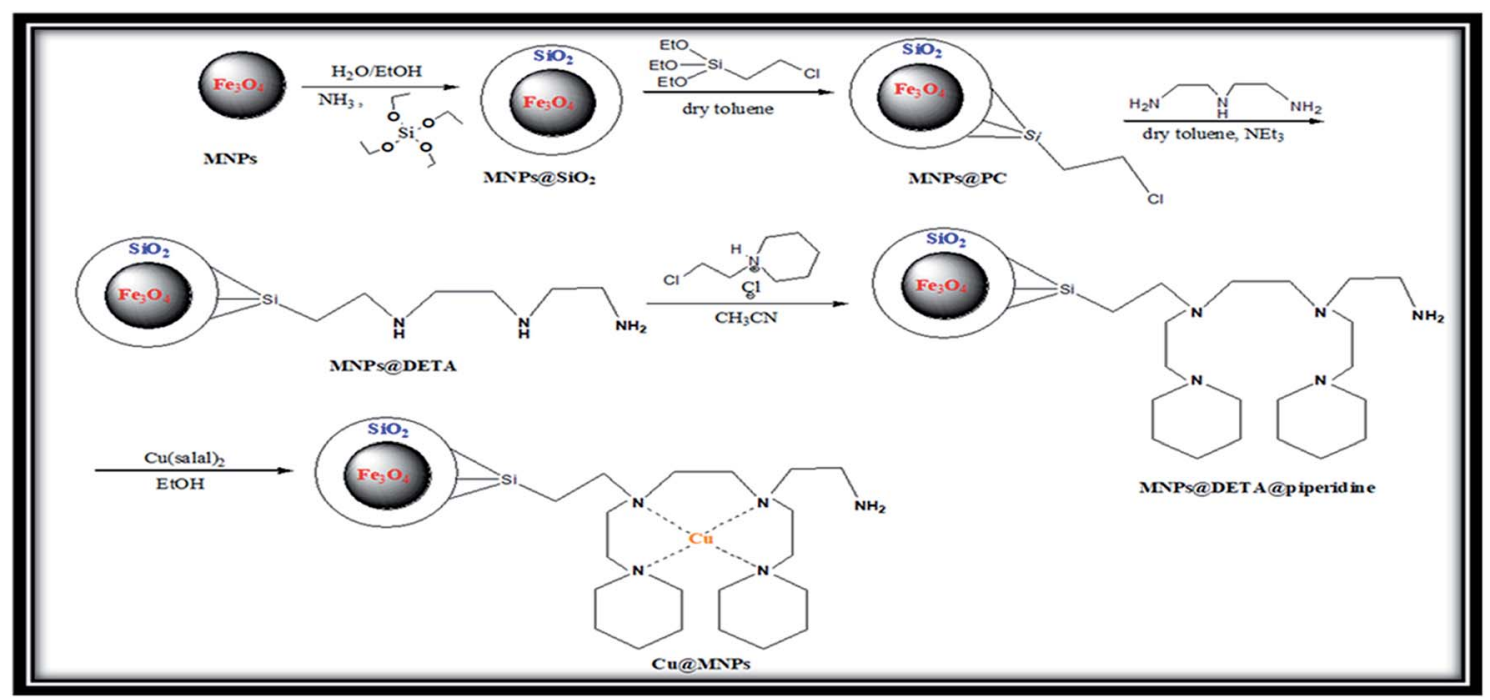

Scheme 1 All stages of the MNPs@Cu synthesis. 


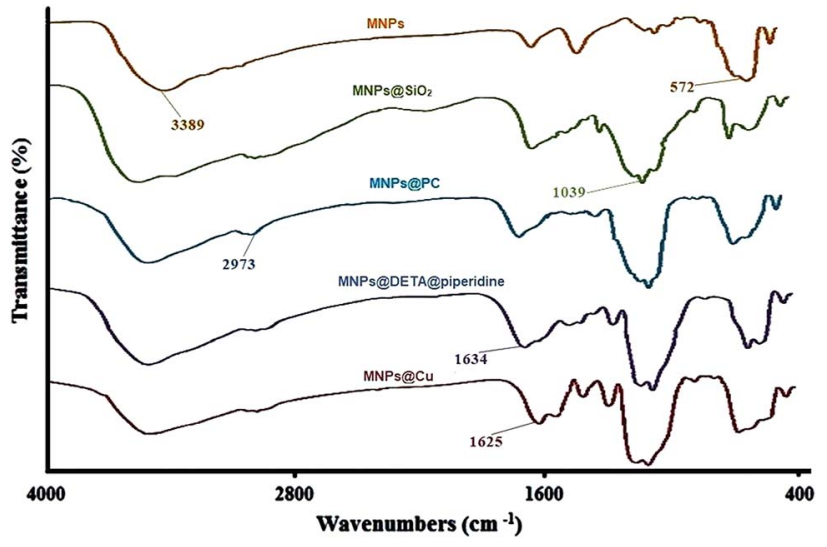

Fig. 1 FTIR spectra of MNPs, MNPs@SiO 2, MNPs@PC, MNPs@DETAapiperidine, and MNPsaCu.

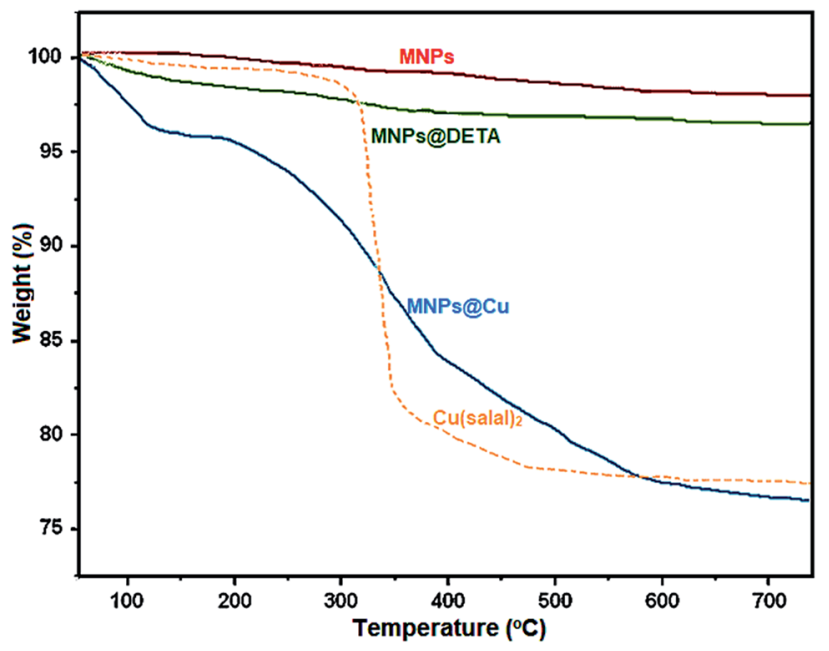

Fig. 2 TGA curves of MNPs, MNPs(aDETA, Cu(salal) ${ }_{2}$ and MNPsaCu.

and the mixture was refluxed for $24 \mathrm{~h}$ under nitrogen atmosphere. At the end of the reaction, the solid phase was separated from the solvent by a powerful magnet and then washed several times with ethanol and distilled water. Eventually, the resulted product (MNPs@PC) was dried in a vacuum oven.

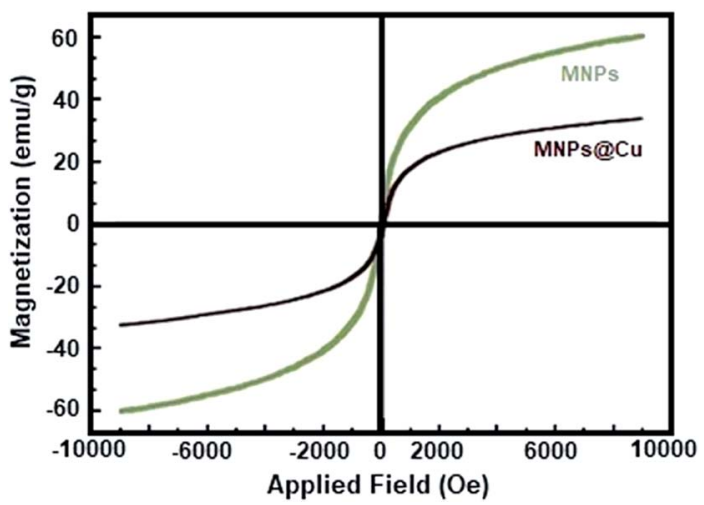

Fig. 3 VSM magnetization curves corresponding to the bare MNPS and MNPs@Cu.

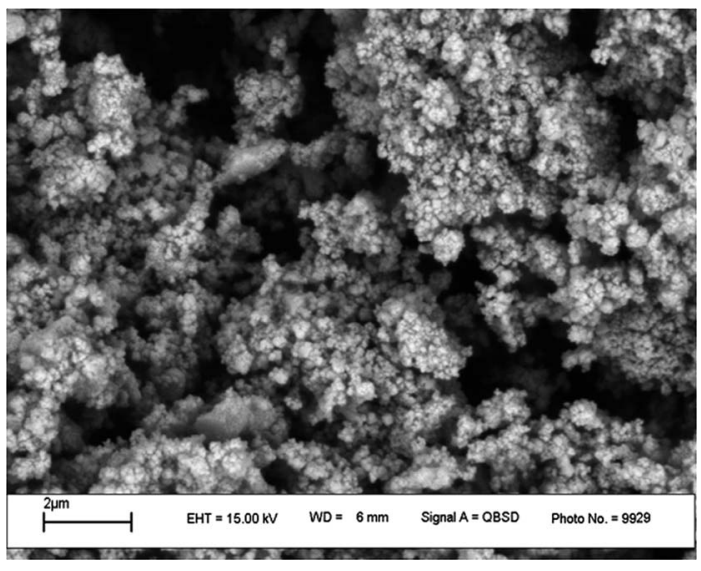

Fig. 4 SEM image of MNPs@Cu.

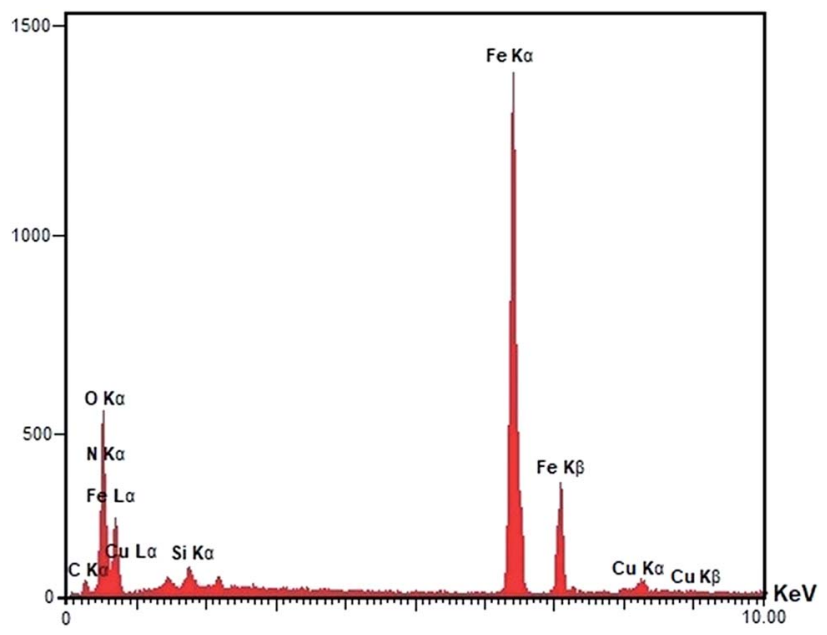

Fig. 5 EDX spectra of MNPsaCu.

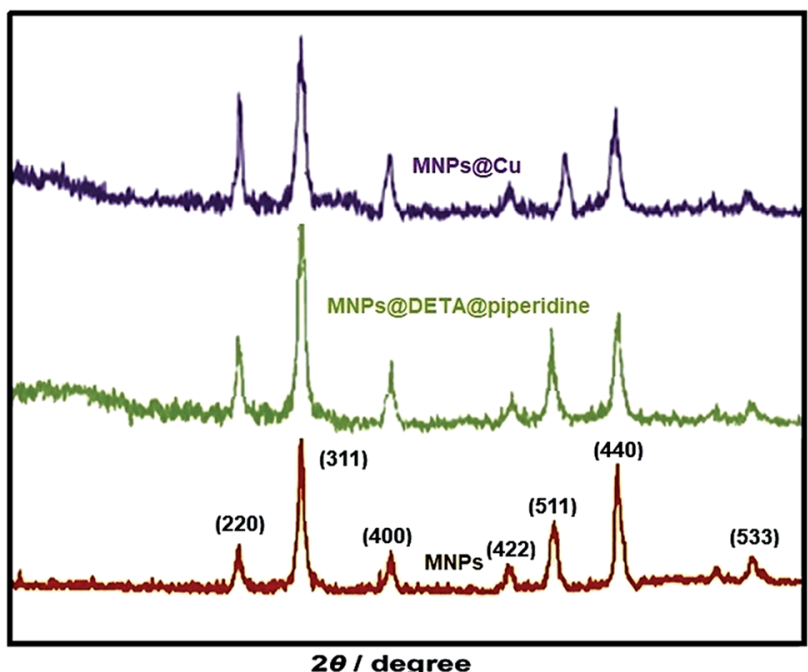

Fig. 6 The XRD patterns of MNPs, MNPs@DETA@piperidine, and MNPsaCu. 


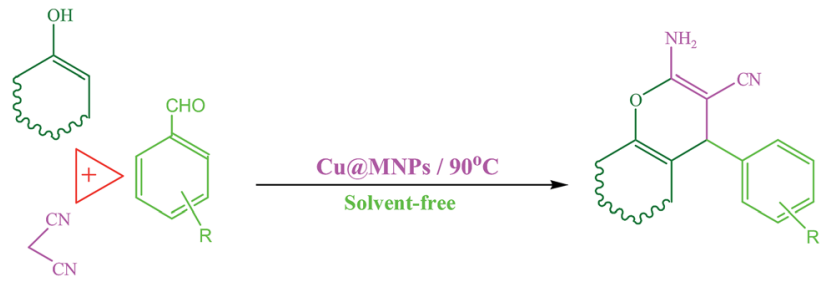

Scheme 2 Synthesis of 2-amino-3-cyano-4H-pyran derivatives using MNPs@Cu.

Preparation of MNPs bonded $N$-propyl diethylenetriamine (MNPs@DETA). The prepared MNPs@PC (2 g) was dispersed in $100 \mathrm{~mL}$ of dry toluene for $30 \mathrm{~min}$ through sonication. Then, it was mixed with diethylenetriamine $(5 \mathrm{~mL})$ and triethylamine $(1$ $\mathrm{mL}$ ) under reflux and nitrogen atmosphere and agitated for $12 \mathrm{~h}$. The resultant solid (MNPs@DETA) was isolated using a permanent magnet and rinsed with ethanol several times to eliminate the unreacted excess of the organic compounds and next dried in a vacuum oven.

Preparation of MNPs@DETA@piperidine. The prepared MNPs@DETA (2 g) dispersed in $100 \mathrm{~mL}$ of acetonitrile was mixed with 1-(2-chloroethyl) piperidine $(3 \mathrm{~g})$ and the resultant mixture was agitated at $80{ }^{\circ} \mathrm{C}$ for $12 \mathrm{~h}$. The resultant solid (MNPs@DETA@piperidine) was isolated using an external magnet and rinsed with water several times to eliminate the unreacted excess of the inorganic salts and next dried in a vacuum oven.

Coordination of $\mathrm{Cu}(\mathrm{II})$ with MNPs@DETA@piperidine. A mixture of MNPs@DETA@piperidine (1 g) and [Cu(salal $\left.)_{2}\right]$ (2 g) was dissolved in $20 \mathrm{~mL}$ of ethanol and then was stirred for $24 \mathrm{~h}$ under dry argon atmosphere. At the end of the reaction, the resultant precipitate MNPs@Cu formed was separated by filtration, washed twice with ethanol $(15 \mathrm{~mL})$ to remove unreacted metal precursors, and dried under vacuum oven to

Table 1 Optimization of the three-component reaction of 4-hydroxycoumarin (1), 4-chlorobenzaldehyde (2e), and malononitrile (3) under various conditions ${ }^{a}$



${ }^{a}$ Reaction conditions: 4-hydroxycoumarin $(1 \mathrm{mmol}), 4$-chlorobenzaldehyde $(1 \mathrm{mmol})$, malononitrile $(1.1 \mathrm{mmol})$, and required amount of the catalysts. ${ }^{b}$ The yields refer to the isolated product.

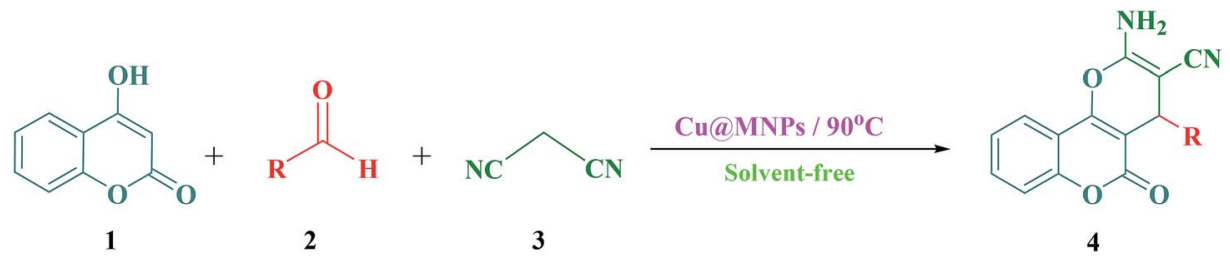

Scheme 3 One-pot three-component condensation of 4-hydroxycoumarin (1), various aldehydes (2), and malononitrile (3). 
Table 2 MNPs@Cu-catalyzed synthesis of 2-amino-3-cyano-pyrano[3,2-c] chromen-5(4H)-one (4) derivatives ${ }^{a}$

\begin{tabular}{lllllll}
\hline Entry & Product & RCHO $(2)$ & Time $(\mathrm{min})$ & Yield $(\%)^{\mathrm{b}}$ & MP (obsd) $\left({ }^{\circ} \mathrm{C}\right)$ & MP $($ lit. $)\left({ }^{\circ} \mathrm{C}\right)$ \\
\hline & $4 a$ & 12 & 91 & $258-260$
\end{tabular}

2

4b<smiles>O=Cc1cccc([N+](=O)[O-])c1</smiles>

$4 c$<smiles>O=Cc1ccc([N+](=O)[O-])cc1</smiles>

4d<smiles>O=Cc1ccccc1Cl</smiles>

4 e<smiles>O=Cc1ccc(Cl)cc1</smiles>

4f<smiles>O=Cc1ccc(F)cc1</smiles>

$4 \mathrm{~g}$<smiles>COc1ccccc1C=O</smiles>

$4 h$<smiles>COc1cccc(C=O)c1</smiles>

$4 \mathbf{i}$<smiles>COc1ccc(C=O)cc1</smiles>

10

$4 \mathbf{j}$<smiles>COc1ccc(C=O)cc1OC</smiles>

11

$4 k$<smiles>COc1cc(C=O)ccc1O</smiles>

41<smiles>Cc1ccccc1C=O</smiles><smiles>Cc1ccc(C=O)cc1</smiles>

13

$4 m$<smiles>N#CC1=C(N)Oc2c(c(=O)oc3ccccc23)C1c1cccc([N+](=O)[O-])c1</smiles><smiles>N#CC1=C(N)Oc2c(c(=O)oc3ccccc23)C1c1ccc([N+](=O)[O-])cc1</smiles>

8<smiles>N#CC1=C(N)Oc2c(c(=O)oc3ccccc23)C1c1ccccc1Cl</smiles><smiles></smiles>

8<smiles>Cc1c(C(C)c2ccc(F)cc2)c(=O)oc2ccccc12</smiles><smiles>COc1ccccc1C1C(C#N)=C(N)Oc2c1c(=O)oc1ccccc21</smiles><smiles>COc1cccc(C2C(C#N)=C(N)Oc3c2c(=O)oc2ccccc32)c1</smiles><smiles>COc1ccc(C2C(C#N)=C(N)Oc3c2c(=O)oc2ccccc32)cc1</smiles><smiles>COc1ccc(C(c2c(O)c3ccccc3oc2=O)C(C)C)cc1OC</smiles><smiles>CC1=C(N)Oc2c(c(=O)oc3ccccc23)C1c1ccccc1C</smiles><smiles>Cc1ccc(C2C(C#N)=C(N)Oc3c2c(=O)oc2ccccc32)cc1</smiles>

12

8

94

95

95

8

15

20

15

20

15

15

92

94

249-251

243-245

262-264

259-261

233-235

90

93

90

92

256-259

$253-254^{47}$

15

90

261-264

$260-262^{17}$

250-252

$252-254^{17}$ 
Table 2 (Contd.)

\begin{tabular}{llllll}
\hline Entry Product & $\mathrm{RCHO}(2)$ & Yield $(\%)^{\mathrm{b}}$ & $\mathrm{MP}(\mathrm{obsd})\left({ }^{\circ} \mathrm{C}\right)$ & $\mathrm{MP}(\mathrm{lit}).\left({ }^{\circ} \mathrm{C}\right)$ \\
${ }^{a}$ & &
\end{tabular}

obtain the pure product. All stages of the MNPs@Cu synthesis are shown in Scheme 1.

General procedure for the synthesis of 2-amino- $4 \mathrm{H}$ chromenes (4, 6, 9 and 10)

A mixture of, enolizable compound (1, 5, 7-8, and $1 \mathrm{mmol})$, malononitrile (1.1 mmol), aldehyde (1 mmol), and MNPs@Cu was combined with each other at $90{ }^{\circ} \mathrm{C}$ under solvent-free conditions. The development of the reaction was controlled with TLC analyses. At the end of the reaction, the mixture was rinsed with water and next, recrystallized from ethanol to achieve the pure product.

\section{Results and discussion}

\section{Catalyst characterization}

FTIR analysis of MNPs@Cu. The corresponding FT-IR spectra of the MNPs, MNPs@SiO ${ }_{2}$, MNPs@PC, MNPs@DETA@piperidine, and MNPs@Cu samples in the region of 400$4000 \mathrm{~cm}^{-1}$ are presented in Fig. 1. The bands at 572 and $3389 \mathrm{~cm}^{-1}$ in the $\mathrm{Fe}_{3} \mathrm{O}_{4}$ MNPs are related to the $\mathrm{Fe}-\mathrm{O}$ stretching frequency and the $\mathrm{OH}$ groups attached to the iron, respectively. In the case of MNPs@SiO ${ }_{2}$, the band's appeared at $1039 \mathrm{~cm}^{-1}$ can be ascribed to the stretching vibration of the $\mathrm{Si}-\mathrm{O}$ groups. In about the MNPs@PC, the absorption bands at $2973 \mathrm{~cm}^{-1}$ are associated to the $\mathrm{C}-\mathrm{H}$ stretching vibration mode. The obtained FT-IR spectra for MNPs@DETA@piperidine contained characteristic amine stretching vibrations at $1634 \mathrm{~cm}^{-1}$ related to diethylene triamine and piperidine groups. In the case of MNPs@Cu, the signals at $1634 \mathrm{~cm}^{-1}$ are shifted to $1625 \mathrm{~cm}^{-1}$. The results clearly proved the effective coordination of metal groups with MNPs@DETA@piperidine.
Thermal analysis of MNPs@Cu. As observed in Fig. 2, the thermal constancy of the MNPs, MNPs@DETA, Cu(salal) ${ }_{2}$, and MNPs@Cu were measured by thermogravimetric analysis (TGA) under a nitrogen atmosphere at $10^{\circ} \mathrm{C} \mathrm{min}^{-1}$ of heating rate. The TGA of $\mathrm{Cu}(\text { salal })_{2}$ has three stages: below $250{ }^{\circ} \mathrm{C}, 300-400{ }^{\circ} \mathrm{C}$, and $400-500{ }^{\circ} \mathrm{C}$ which is related with the decomposition of salicylic chelate ligand. TGA data for another three samples show approximately $5 \%$ weight loss below $200{ }^{\circ} \mathrm{C}$ due to the dehydration of the surface hydroxy groups as well as desorption of physically adsorbed solvents. In the TGA graph of MNPs@DETA, a mass percentage loss of about 9\% appeared that is related with the organic parts decomposition. The TGA of MNPs@Cu undergoes four stages of thermal degradation with a more mass loss at about $24.5 \%$. In addition to the mentioned step in the range below $250{ }^{\circ} \mathrm{C}$, the second stage can be seen in the range between $300-400{ }^{\circ} \mathrm{C}$, which can be related to the elimination of salicylic chelate ligand. The second stage occurs in the range between $500-600{ }^{\circ} \mathrm{C}$ which is attributed to formation of a $\mathrm{Fe}-\mathrm{O}-\mathrm{Cu}$ bond and, finally, at $650{ }^{\circ} \mathrm{C}$ because of the decomposition of MNPs.

VSM analysis of MNPs@Cu. To investigate the magnetic properties of the MNPs and MNPs@Cu, magnetic measurements were performed by means of a vibrating sample magnetometer (VSM) with the field sweeping from -8500 to +8500 Oersted at ambient temperature (Fig. 3). As shown in VSM patterns, the saturation magnetization $\left(M_{\mathrm{s}}\right)$ values of MNPs and MNPs@Cu are 60.39 and $34.55 \mathrm{emu}^{-1}$, respectively.

SEM analysis of MNPs@Cu. The morphology and size of the MNPs@Cu were surveyed to determine the variations in the surface of this nanocatalyst by the SEM analysis (Fig. 4). The SEM image of MNPs@Cu shows that the catalyst has a nearly spherical structure with nanometer-sized particles.



Scheme 4 One-pot three-component reaction of dimedone (5), different aldehydes (2) and malononitrile (3). 
Table 3 MNPs@Cu-catalyzed synthesis of 2-amino-3-cyano-7,8-dihydro-4H-chromen-5(6H)-one (6)derivatives ${ }^{a}$

\begin{tabular}{|c|c|c|c|c|c|c|c|}
\hline Entry & Product & RCHO (2) & Product & Time (min) & Yield $(\%)^{\mathrm{b}}$ & $\mathrm{MP}($ obsd $)\left({ }^{\circ} \mathrm{C}\right)$ & MP (lit.) \\
\hline 1 & $6 a$ & & & 17 & 91 & $232-234$ & $234-235^{49}$ \\
\hline
\end{tabular}

2<smiles>O=Cc1cccc([N+](=O)[O-])c1</smiles>

$6 c$<smiles>O=Cc1ccc([N+](=O)[O-])cc1</smiles>

6d

4<smiles>O=Cc1ccccc1Cl</smiles>

$6 e$<smiles>O=Cc1ccc(Cl)cc1</smiles>

$6 f$<smiles>O=Cc1cccc(Br)c1</smiles>

$6 \mathrm{~g}$<smiles>O=Cc1ccc(Br)cc1</smiles>

$6 h$

8

9

10

6j

$6 \mathbf{i}$<smiles>N#Cc1ccc(C=O)cc1</smiles><smiles>O=Cc1ccc(F)cc1</smiles><smiles>CC1CC(=O)C2=C(C1)OC(N)=C(C#N)C2c1cccc([N+](=O)[O-])c1</smiles>

15<smiles>CC1CC(=O)C2=C(C1)OC(N)=C(C#N)C2c1ccc([N+](=O)[O-])cc1</smiles>

15<smiles>CC1(C)CC(=O)C2=C(OC(N)=C(C#N)C2c2ccccc2Cl)O1</smiles>

15<smiles>CC1(C)CC(=O)C2=C(C1)OC(N)=C(C#N)C2c1ccc(Cl)cc1</smiles>

15<smiles>CC1(C)CC(=O)C2=C(C1)OC(N)=C(C#N)C2c1cccc(Br)c1</smiles>

20<smiles>CC1CC(=O)C2=C(C1)OC(N)=C(C#N)C2c1ccc(Br)cc1</smiles>

15<smiles>CC1CC(=O)C2=C(C1)OC(N)=C(C#N)C2c1ccc(F)cc1</smiles>

15<smiles>CC1CC(=O)C2=C(C1)OC(N)=C(C#N)C2c1ccc(C#N)cc1</smiles>

15
94

92

95

93

94

92

95

92

225-229

217-220

91

90

180-182

207-210

212-214

229-231

208-211

207-209
$214-216^{23}$

$179-180^{25}$

$198-200^{24}$

$215-217^{23}$

$228-230^{32}$

$207-209^{52}$

$210-211^{49}$<smiles>COc1ccc(C2C(C#N)=C(N)OC3=C2C(=O)CC(C)(C)C3)cc1</smiles><smiles>COc1ccc(C=O)cc1</smiles> 
Table 3 (Contd.)

Entry Product

\footnotetext{
${ }^{a}$ Reaction conditions: dimedone $(1 \mathrm{mmol})$, aldehyde $(1 \mathrm{mmol})$, malononitrile $(1.1 \mathrm{mmol})$, MNPs@Cu $(10 \mathrm{mg}) .{ }^{b}$ The yields refer to Isolated products.
}

EDX analysis of MNPs@Cu. Energy dispersive X-ray (EDX) mapping was carried out to verify the components of MNPs@Cu nanocatalyst (Fig. 5). The EDX analysis proved the presence of Fe, $\mathrm{O}, \mathrm{Si}, \mathrm{C}, \mathrm{N}$, and $\mathrm{Cu}$ characteristic peaks. Moreover, the appearance of copper bands in the nanocatalyst demonstrates the successful immobilization of copper(II) complex on the MNPs surface.

XRD analysis of MNPs@Cu. X-ray diffraction (XRD) is an effectual spectra method for the identification of the synthesis of magnetite crystal phase in the magnetic nano-catalyst. Fig. 6 exhibits the XRD patterns corresponding to the MNPs, MNPs@DETA@piperidine, and MNPs@Cu. In the XRD patterns of the all samples, the reflections at the values of $2 \theta-$ which are 30.27 (220), 35.34 (311), 43.73 (400), 54.45 (422), 57.51 (511), 63.19 (440), and 74.58 (533) - correspond to the spinel phase of magnetic iron oxide nanoparticles and are good agreement with (JCPDS card no. 79-0417). In the case of MNPs@DETA@piperidine, and MNPs@Cu, the broad reflection in $2 \theta=15-27^{\circ}$ is related to an amorphous silica shell. Therefore, it is concluded that the MNPs@Cu catalyst was synthesized successfully without damaging the crystalline structure of the MNPs core.
In current research, we reported our results for the efficient and rapid synthesis of 2-amino-3-cyano- $4 H$-pyrans using MNPs@Cu as an effective and reusable heterogeneous nanocatalyst under solvent-free conditions (Scheme 2).

To monitor the reaction conditions for synthesizing 2amino-4-(4-chlorophenyl)-3-cyano-pyrano[3,2-c] chromene$5(4 H)$-one (4e), the influence of the reaction temperature, the solvent, and the amounts of magnetic nanocatalyst were studied in the reaction of 4-hydroxycoumarin (1), 4-chlorobenzaldehyde (2e), and malononitrile (3) (molar ratio: $1: 1: 1.1)$ as a model reaction. The outcomes are presented in Table 1. To obtain the optimal reaction solvent, different solvents such as $\mathrm{H}_{2} \mathrm{O}, \mathrm{CH}_{2} \mathrm{Cl}_{2}, \mathrm{CH}_{3} \mathrm{CN}$, DMF, toluene, and EtOH in the existence of a certain amount of magnetic nanocatalyst were used. The trial reaction in the existence of EtOH, as a solvent, afforded the highest percentage of the target product 4e (Table 1, Entry 6) but the most favorable conditions in terms of rate and yield were obtained under solvent-free conditions for the reaction (Table 1, Entry 10). In the following phase of the survey, the influence of temperature on the completion of the



Scheme 5 One-pot three-component reaction of $\mathrm{C}-\mathrm{H}$-activated acids (7-8), different aldehydes (2) and malononitrile (3a). 
Table 4 MNPs@Cu catalyzed synthesis of 2-amino-3-cyano-4H-pyran (9-10) derivatives ${ }^{a}$

MP (lit.) ( $\left.{ }^{\circ} \mathrm{C}\right)$

1<smiles>O=Cc1ccccc1</smiles>

9b<smiles>O=Cc1ccc(Cl)cc1</smiles>

$9 c$<smiles>O=Cc1ccc(F)cc1</smiles><smiles>Cc1cc2c(c(=O)o1)C(c1ccccc1)C(C#N)=C(N)O2</smiles>

9d<smiles>O=Cc1ccc(Br)cc1</smiles>

9e<smiles>O=Cc1ccc([N+](=O)[O-])cc1</smiles>

9f<smiles>COc1ccc(C=O)cc1</smiles><smiles>O=Cc1ccccc1</smiles>

10a

8

$10 b$<smiles>O=Cc1ccc(Cl)cc1</smiles>

9

10c<smiles>O=Cc1ccc(F)cc1</smiles>

10

10d

11

$10 \mathrm{e}$<smiles>Cc1cc2c(c(=O)o1)C(c1ccc(Br)cc1)C(C#N)=C(N)O2</smiles>

15

15<smiles>Cc1cc2c(c(=O)o1)C(c1ccc([N+](=O)[O-])cc1)C(C#N)=C(N)O2</smiles>

25<smiles>COc1ccc(C2C(C)=COc3cc(C)oc(=O)c32)cc1</smiles>

25

20<smiles>Cc1cc2c(c(=O)[nH]1)C(c1ccc(Cl)cc1)C(C#N)=C(N)O2</smiles>

20<smiles>Cc1cc2c(c(=O)[nH]1)C(c1ccc(F)cc1)C(C#N)=C(N)O2</smiles>

20<smiles>Cc1cc2c(c(=O)[nH]1)C(c1ccc(Br)cc1)C(C#N)=C(N)O2</smiles>

20
20

15<smiles>Cc1cc2c(c(=O)o1)C(c1ccc(Cl)cc1)C(C#N)=C(N)O2</smiles>

15<smiles>Cc1cc2c(c(=O)o1)C(c1ccc(F)cc1)C(C#N)=C(N)O2</smiles>

91

94

95

93

94

88

91

92

93

92<smiles>Cc1cc2c(c(=O)[nH]1)C(c1ccc([N+](=O)[O-])cc1)C(C#N)=C(N)O2</smiles>

237-239

$236-238^{53}$

233-230

$231-232^{54}$

224-221

$223-225^{55}$

217-215

$218-220^{55}$

$220-222^{56}$

212-209

$210-212^{57}$

$279-282^{58}$

242-245

$245-247^{58}$

258-261

$258-259^{55}$

94

276-279

$278-279^{55}$ 
Table 4 (Contd.)

\begin{tabular}{llllll}
\hline Entry Product & RCHO (2) & Product & Time (min) & Yield $^{b}(\%)$ & MP (obsd) $\left({ }^{\circ} \mathrm{C}\right)$ \\
\hline 12
\end{tabular}
${ }^{a}$ Reaction conditions: $\mathrm{C}-\mathrm{H}$-activated acid $(7$ and 8$)(1 \mathrm{mmol})$, aldehyde $(1 \mathrm{mmol})$, malononitrile $(1.1 \mathrm{mmol}), \mathrm{MNPs} @ \mathrm{Cu}(10 \mathrm{mg}) \cdot{ }^{b}$ The yields refer to
isolated products.

reaction was investigated (Entries $8-12$ and 14$)$. Without heating, the reaction rate was very low and the yield was negligible (Table 1, Entry 14). The yield of the product increased up to $90{ }^{\circ} \mathrm{C}$ (Table 1, Entries 8-10), after which no enhancement was observed by increasing the temperature (Table 1, Entries 11 and 12). To obtain the optimum amount of magnetic nanocatalyst MNPs@Cu, diverse concentrations of nanocatalyst $(5,10$, and $15 \mathrm{mg}$ ) were used to compare the reaction efficiency (Table 1 , Entries 10, 13 and 15). After several screening tests with different concentrations of the nanocatalyst, it was found that the maximum yield (i.e., 95\%) at the short reaction time was achieved when $10 \mathrm{mg}$ of MNPs@Cu was applied under solventfree conditions (Entry 10). Enhancing the concentration of catalyst beyond $10-15 \mathrm{mg}$ did not lead to any substantial progress in the product yield (Table 1, Entry 15) whereas the lower amount of catalyst needed for the reaction from $10 \mathrm{mg}$ to $5 \mathrm{mg}$ led to reducing the efficiency of the reaction (Table 1, Entry 13). Without using the catalyst, the product yields fell sharply and some stain was observed on thin-layer chromatography (TLC) (Table 1, Entry 7). Finally, when the model reaction was accomplished in the presence of 10 mg of MNPs@DETA@piperidine and $\mathrm{Cu}(\mathrm{salal})_{2}$ under the optimized conditions, the yield of the product were 85 and $78 \%$, respectively (Table 1, Entries 16 and 17). The favourable comparison of the

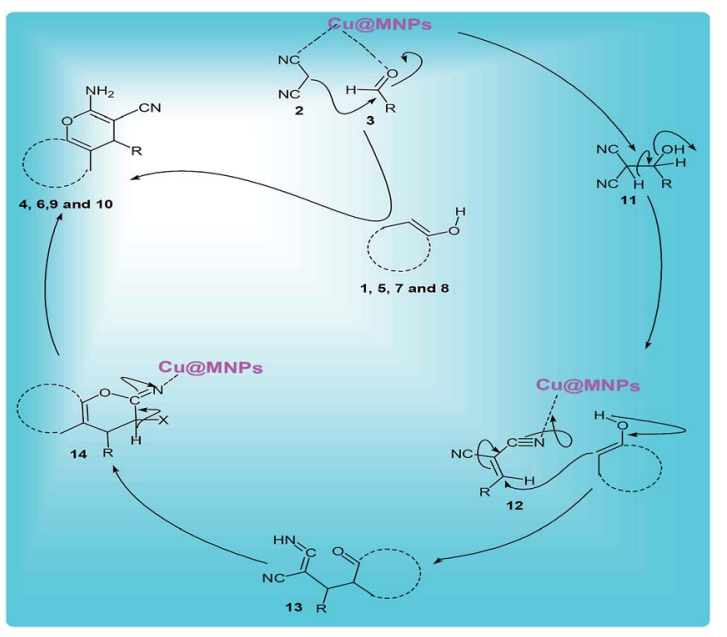

Scheme 6 A plausible mechanism for the one-pot three-component reaction of various enols $(1,5,7$, and 8 ), aldehydes (2), and malononitrile (3) catalyzed by MNPs@Cu under solvent-free conditions. corresponding values for inputs 10,16 , and 17 accurately indicates that the catalyst activity increases when MNPs@DETA@piperidine is coordinate to the $\mathrm{Cu}(\text { salal })_{2}$ through the lone pair of nitrogen.

In order to generalize the optimum conditions (Table 1, Entry 10), we investigated the generality of this method with a range of appropriate aldehydes to prepare a series of 2-amino3-cyano-pyrano[3,2-c] chromen-5(4H)-one derivatives (4a-o) under similar conditions (Scheme 3 ). The optimized results are represented in Table 2. It was observed that the aryl aldehydes reacted very well with both electron-withdrawing and electrondonating substituents and resulted the relating 2-amino-3cyano-pyrano[3,2-c] chromen-5(4H)-one derivatives with high purity in good yields. The further precise analysis shows that aryl aldehydes having an electron-donating group (entries 7-15, Table 2) react slower compared to aryl aldehydes having electron withdrawing groups (entries 1-6, Table 2).

In the following, to expand the use of this nanomagnetic catalyst to the other reactions of these categories, a series of polyfunctionalized 2-amino-3-cyano-7,8-dihydro- $4 \mathrm{H}$-chromen$5(6 H)$-one derivatives $(\mathbf{6 a}-\mathbf{n})$ were prepared from the reaction mixture of dimedone (5), different aldehydes (2a-n), and malononitrile (3) under the optimized reaction conditions mentioned above (Scheme 4). In this case, the use of dimedone, as an enolic component, improved the reaction time of the desired product 6 slightly (Table 3).

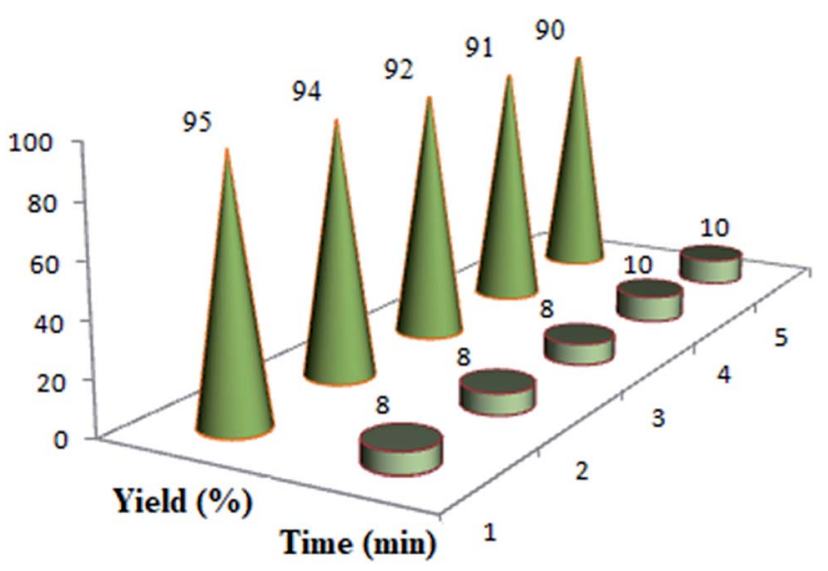

Fig. 7 The recycling of MNPs@Cu as a nanomagnetic catalyst under solvent-free conditions. 
Table 5 Comparison of the current method with other reported strategies for synthesizing 2-amino-4-(4-chlorophenyl)-3-cyano-pyrano[3,2c] chromene-5(4H)-one

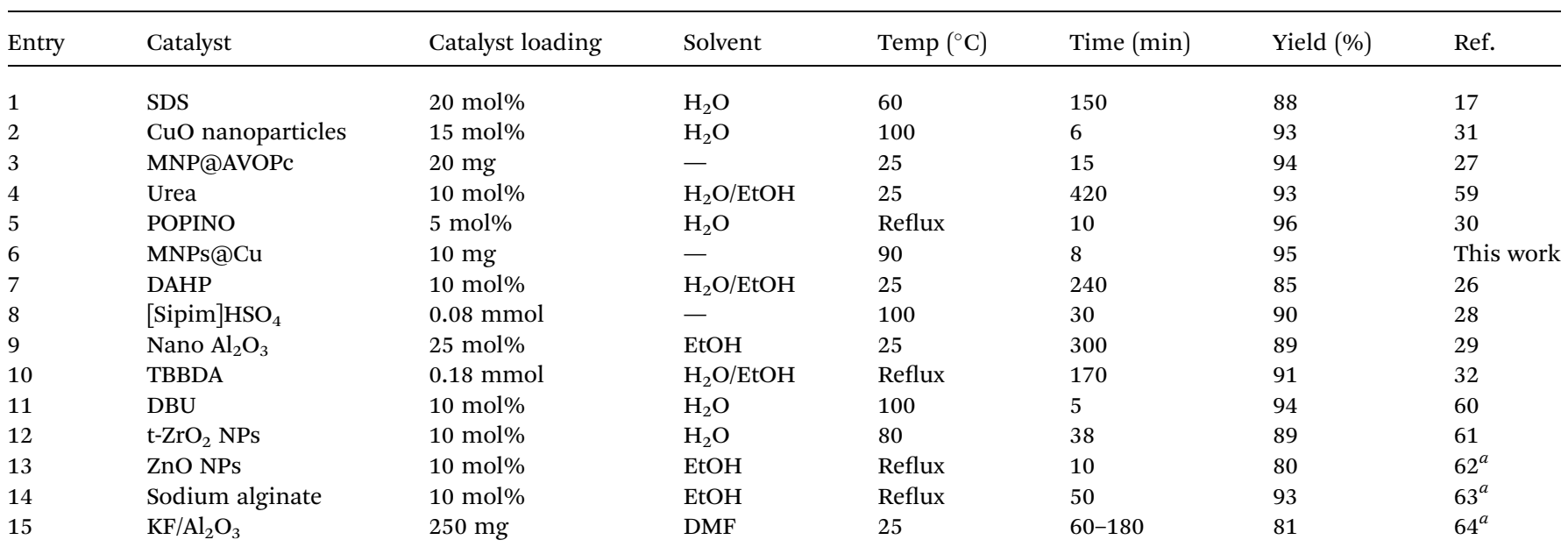

${ }^{a}$ Reaction conditions: dimedone (1 mmol), 4-chlorobenzaldehyde $(1 \mathrm{mmol})$, malononitrile $(1 \mathrm{mmol})$.

After the successful synthesis of 2-amino-3-cyano-7,8-dihydro- $4 H$-chromen-5 $(6 H)$-one derivatives in good to excellent yields, it was attempted to synthesize 2-amino-3-cyano-pyrano [4,3- $b]$ pyran-5(4H)-ones (9a-9f) and 2-amino-3-cyano-pyrano $[3,2-c]$ pyridine- $6(5 H)$-ones (10a-10f) under similar conditions. For this purpose, were placed the 4-hydroxy-6-methylpyrone 9 and 4-hydroxy-6-methylpyridone 10 compounds with dimedone in the same conditions (Scheme 5). In this case, the use of $\mathrm{C}-\mathrm{H}-$ activated acids, as cyclic 1,3-dicarbonyls, required longer reaction times compared to 4-hydroxycoumarin (1) under similar reaction conditions (Table 4).

A plausible mechanism for the preparation of 2-amino- $4 H^{-}$ chromene derivatives catalyzed by MNPs@Cu is shown in Scheme 6. Initially, malononitrile 2 and aldehyde 3 as the reactant components react with each other via a Knoevenagel condensation reaction. MNPs@Cu coordinate with the $\mathrm{C} \equiv \mathrm{N}$ and $\mathrm{C}=\mathrm{O}$ functional groups of aldehyde and malononitrile, respectively, thus increasing the activity of these groups. After passing the transition state $\mathbf{1 1}$ and a dewatering step, it creates alkylidene malononitrile 12. Then, enolate of the $\mathrm{C}-\mathrm{H}$-activated acid $(\mathbf{1}, \mathbf{5}, 7$, and $\mathbf{8})$ by Michael addition is added to this activated intermediate by MNPs@Cu and the polar transition state 13 is created. This compound is unstable and is converted by tautomerization to the intermediate $\mathbf{1 4}$, which generates products $4,6,9$, and 10 though cyclization reaction.

To evaluate the recycled MNPs@Cu performance, after five periods of recycling, this nanocatalyst was reused in the threecomponent reaction of 4-hydroxycoumarin, 4-chlorobenzaldehyde, and malononitrile as a model reaction (Fig. 7). Negligible changes in the reaction efficiency represent the nanocatalyst performance and expression of the costeffectiveness of our method.

As clearly shown Table 5, although all the mentioned homogeneous and heterogeneous catalysts are suitable for synthesizing 2-amino- $4 \mathrm{H}$-chromene derivatives, most of them suffer from one or more disadvantages, like the usage of toxic organic solvents, long reaction times, high catalyst loading, and tedious work-up procedures. It is clear that a suitable methodology in terms of the compatibility with the environment, product yield, using green solvent, and reaction time in the existence of a low catalyst loading of MNPs@Cu comparing with several other catalysts has been developed.

\section{Conclusion}

In general, we described an easy, effective, and ecofriendly method for a wide range of biologically and pharmacologically interesting functionalized 2-amino- $4 \mathrm{H}$-chromenes one in the existence of an environmental friendly and reusable nanocatalyst (MNPs@Cu) via one-pot Knoevenagel condensation of $\mathrm{C}-\mathrm{H}$-activated acids, aldehydes, and malononitrile under solvent-free conditions. This method suggests various privileges including the usage of a green catalyst, lower loading of the catalyst, no organic solvent, easy work-up, and good to high yields.

\section{Conflicts of interest}

There are no conflicts to declare.

\section{References}

1 F. Al-Assar, K. N. Zelenin, E. E. Lesiovskaya, I. P. Bezhan and B. A. Chakchir, Pharm. Chem. J., 2002, 36, 598.

2 R. P. Jain and J. C. Vederas, Bioorg. Med. Chem. Lett., 2004, 14, 3655.

3 S. J. Mohr, M. A. Chirigos, F. S. Fuhrman and J. W. Pryor, Cancer Res., 1975, 35, 3750.

4 M. Rueping, E. Sugiono and E. Merino, Chem.-Eur. J., 2008, 14, 6329.

5 L. Hanna and A. Calanolide, Bulletin of Experimental Treatments for AIDS (BETA), 1998, vol. 12, p. 8.

6 M. T. Flavin, J. D. Rizzo, A. Khilevich, A. Kucherenko, A. K. Sheinkman, V. Vilaychack, L. Lin, W. Chen, 
E. M. Greenwood, T. Pengsuparp, J. M. Pezzuto, S. H. Hughes, T. M. Flavin, M. Cibulski, W. A. Boulanger, R. L. Shone and Z. Q. Xu, J. Med. Chem., 1996, 39, 1303.

7 D. O. Moon, K. C. Kim, C. Y. Jin, M. H. Han, C. Park, K. J. Lee, Y. M. Park, Y. H. Choi and G. Y. Kim, Int. Immunopharmacol., 2007, 7, 222.

8 T. Raj, R. K. Bhatia, A. Kapur, M. Sharma, A. K. Saxena and M. P. S. Ishar, Eur. J. Med. Chem., 2010, 45, 790.

9 L. Bonsignore, G. Loy, D. Secci and A. Calignano, Eur. J. Med. Chem., 1993, 28, 517.

10 A. G. Martinez and L. J. Marco, Bioorg. Med. Chem. Lett., 1997, 7, 3165.

11 L. L. Andreani and E. Lapi, Bull. Chim. Farm., 1960, 99, 583.

12 Y. L. Zhang, B. Z. Chen, K. Q. Zheng, M. L. Xu, X. H. Lei and X. B. Yaoxue, Chem. Abstr., 1982, 96, 135383e.

13 E. A. A. Hafez, M. H. Elnagdi, A. G. A. Elagamey and F. M. A. A. Eltaweel, Heterocycles, 1987, 26, 903.

14 A. Shaabani, R. Ghadari, A. sarvary and A. H. Rezayan, J. Org. Chem., 2009, 74, 4372.

15 M. N. Elinson, A. S. Dorofeev, F. M. Miloserdov, A. I. Ilovaisky, S. K. Feducovich, P. A. Belyakov and G. I. Nikishina, Adv. Synth. Catal., 2008, 350, 591.

16 H. J. Bestmann, Angew. Chem., Int. Ed. Engl., 1967, 6(1), 104. 17 H. Mehrabi and H. Abusaidi, J. Iran. Chem. Soc., 2010, 7, 890. 18 A. Shaabani, S. Samadi, Z. Badri and A. Rahmati, Catal. Lett., 2005, 104, 39.

19 M. Khoobi, L. Ma'mani, F. Rezazadeh, Z. Zareie, A. Foroumadi, A. Ramazani and A. Shafiee, J. Mol. Catal. A: Chem., 2012, 359, 74.

20 L. Min, L. Ma and L. Hu, Tetrahedron Lett., 2011, 52, 2597.

21 X. Wang, Z. Zeng, D. Shi, X. Wei and Z. Zong, Synth. Commun., 2004, 34, 3021.

22 S. Jadhava, R. patila, D. Kumbhara, A. Patravaleb, D. Chandamb and M. Deshmukha, Int. J. Pharm. Sci. Rev. Res., 2015, 35, 75.

23 M. Kazemzad, A. A. Yuzbashi, S. Balalaie and M. Bararjanian, Synth. React. Inorg., Met.-Org., Nano-Met. Chem., 2011, 41, 1182.

24 J. K. Rajput and G. Kaur, Catal. Sci. Technol., 2014, 4, 142.

25 S. Balalaie, M. Bararjanian, A. M. Amani and B. Movassagh, Synlett, 2006, 2, 263.

26 S. Gowravaram, K. Arundhathi, K. B. S. Sudhakar and J. S. Yadav, Synth. Commun., 2009, 39, 433.

27 M. Safaiee, M. A. Zolfigol, F. Afsharnadery and S. Baghery, RSC Adv., 2015, 5, 102340.

28 K. Niknam and A. Piran, Green Sustainable Chem., 2013, 3, 1. 29 A. Montaghami and N. Montazeri, Orient. J. Chem., 2014, 30, 1361.

30 M. G. Dekamin, M. Eslami and A. Maleki, Tetrahedron, 2013, 69, 1074.

31 H. Mehrabi and M. Kazemi-Mireki, Chin. Chem. Lett., 2011, 22, 1419.

32 S. Banerjee, A. Horn, H. Khatri and G. A. Sereda, Tetrahedron Lett., 2011, 52, 1878.

33 J. H. Clark, Catalysis for green chemistry, Pure Appl. Chem., 2001, 73, 103.
34 V. J. Mohanraj and Y. Chen, Trop. J. Pharm. Res., 2006, 5, 561. 35 D. Astruc, Inorg. Chem., 2007, 46, 1884.

36 L.-S. Zhong, J.-S. Hu, Z.-M. Cui, L.-J. Wan and W.-G. Song, Chem. Mater., 2007, 19, 4557.

37 M. Moreno-Manas and R. Pleixats, Acc. Chem. Res., 2003, 36, 638.

38 A. Yahyazadeh, E. Abbaspour-Gilandeh and M. AghaeiHashjin, Catal. Lett., 2018, 148, 1254.

39 F. Kamali and F. Shirini, RSC Adv., 2017, 41, 11778.

40 M. Sheykhan, A. Yahyazadeh and Z. Rahemizadeh, RSC Adv., 2016, 6, 34553.

41 X. Zheng, S. Luo, L. Zhang and J. P. Cheng, Green Chem., 2009, 11, 455.

42 W. Xiang-Shan, Z. Zhao-Sen, S. Da-Qing, W. Xian-Yong and Z. Zhi-Min, Chin. J. Org. Chem., 2005, 25, 1138.

43 D. K. Yi, S. S. Lee and J. Y. Ying, Chem. Mater., 2006, 18, 24592461.

44 J. Ramos, A. Millan and F. Palacio, Polymer, 2000, 41, 8461. 45 Z. Ma, Y. Guan and H. Liu, J. Magn. Magn. Mater., 2006, 301, 469.

46 M. J. Khurana, B. Nand and P. Saluja, Tetrahedron, 2010, 66, 5637.

47 W. Hong-juan, Z. jie and Z. Zhan-Hui, Monatsh. Chem., 2010, $141,1107$.

48 G. M. Ziarani, A. Badiei, M. Azizi and P. Zarabadi, J. Chem. Eng., 2011, 30, 59.

49 S. Gao, C. H. Tsai, C. Tseng and C. F. Yao, Tetrahedron, 2008, 64, 9143.

50 R. Liangce, L. Xiaoyue, W. Haiying, S. Daqing, T. Shujiang and Z. Oiya, Synth. Commun., 2006, 36, 2363.

51 A. Patra and T. Mahapatra, J. Chem. Res., Synop., 2010, 34, 689.

52 S. Balalaie, M. Bararjanian, M. Sheikh-Ahmadi, S. Hekmat and P. Salehi, Synth. Commun., 2007, 37, 1097.

53 M. Poliakoff and P. Licence, Nature, 2007, 450, 810.

54 P. Tundo and P. T. Anastas, Green Chemistry: Challenging Perspectives, Oxford University Press, Oxford, UK, 2000, p. 79.

55 X. Fan, D. Feng, Y. Qu, X. Zhang, J. Wang, P. M. Loiseau, G. Andrei, R. Snoeck and E. Clercq, Bioorg. Med. Chem. Lett., 2010, 20, 809.

56 E. V. Stoyanov, I. C. Ivanov and D. Heber, Molecules, 2000, 5, 19.

57 M. Z. Piao and K. Imafuku, Tetrahedron Lett., 1997, 38, 5301. 58 S. M. Baghbanian, RSC Adv., 2014, 4, 59397.

59 G. Brahmachari and B. Banerjee, ACS Sustainable Chem. Eng., 2014, 2, 411.

60 M. Hong and C. Cai, J. Chem. Res., Synop., 2010, 34, 568.

61 A. Saha, S. Payra and Su. Banerjee, RSC Adv., 2015, 5, 101664.

62 S. Zavar, Arabian J. Chem., 2017, 10, S67.

63 M. G. Dekamin, S. Z. Peyman, Z. Karimi, S. Javanshir, M. R. Naimi-Jamal and M. Barikani, Int. J. Biol. Macromol, 2016, 87, 172.

64 X.-S. Wang, D.-Q. Shi, S.-J. Tu and C.-S. Yao, Synth. Commun., 2003, 33, 119. 